\title{
Performance Assessment to Measure Student's Mathematical Proving Ability Based on the Abductive-Deductive Approach
}

\section{Ellis Salsabila, Wardani Rahayu, and Pinta Deniyanti Sampoerno}

Mathematics Education Program, Faculty of Mathematics and Science, State University of Jakarta, Indonesia

\section{Abstract}

This study provides an overview of performance assessment instruments to measure students' mathematical proving abilities based on the abductive-deductive approach. This is descriptive qualitative research of performance assessment instruments and their rubrics in measuring students' mathematical proving abilities. The research method was literature study. The performance assessment instrument consists of essays designed to identify the mathematical proving abilities of students in mathematics courses. In this article, the examples are given for the Real Analysis class. The items of performance

Corresponding Author:

Ellis Salsabila

ellissalsabila@yahoo.com

Published: 11 November 2020

Publishing services provided by Knowledge E

(c) Ellis Salsabila et al. This article is distributed under the terms of the

Attribution License, which

permits unrestricted use and redistribution provided that the original author and source are credited.

Selection and Peer-review under the responsibility of the IC-HEDS 2019 Conference Committee. assessment were arranged referring to the abductive-deductive reasoning approach which has a pattern containing three main questions: 1) "What conditions can be obtained from the conclusion?" which was answered with abductive reasoning, 2) "What are the consequences that can be obtained from known facts?" which can be answered with deductive reasoning, and 3) "What conditions connect the conditions of conclusions and the implications of premise?" which can be answered with a key process of the mathematical statement proving process.

Keywords: performance assessment, mathematical proving ability, abductivedeductive approach

\section{Introduction}

The ability to prove statements, traits, or theorems in mathematics is what usually called the higher order thinking skills (HOTS), which is an ability to think critically (to analyze, synthesize, evaluate) and be creatively (to solve problems, prove and create). Not every student can easily and quickly master the ability of mathematical proving, or at least most students have difficulty to solve the proving problem in mathematics. Selden \& Selden, Epp, William \& Senk, and Douek also stated that most of the students having problem in writing mathematical proving problem [1-4]. 
In fact, many benefits can be obtained from the experience of proving, the proving ability makes mathematics unique and different from other disciplines, proving problems is the main characteristic of mathematical activities, and is a key component in learning mathematics. Dickerson states that there are several reasons why proving lessons needs to be taught to students, including: 1) proving is an integral part of mathematics, 2) to verify and find facts, 3) to develop students' logical and critical thinking skills, and 4) to accelerate and improve students' mathematical understanding [5].

Rippi Maya stated that mathematical proving ability is an ability to do mathematical proving which also used by Deer, Mueller, Platt and Sharon. Initially it was an ability to write proof, then the idea of mathematical proving has been revised and expanded to capture various abilities related to mathematical proving, which include proof construction, proof validation, and the method of proof knowledge [6, 7]. Based on the opinions of Stylianides, Alcock \& Weber, it was concluded that mathematical proving ability is the ability to prove or compile evidence of a mathematical statement in an effort to show the truth or to verify a mathematical statement through a process of deductive reasoning which involves the ability to organize and manipulate a series of arguments (premise, definition, lemma, theorem or a proven statement) and the ability to compose logical steps to reach the conclusion of the mathematical statement [1,7-9].

In universities, research related to mathematical proving, especially proof in group theory (abstract algebra), has been done by Arnawa which concluded that most students still have difficulty in making proof [10]. Efforts to overcome student difficulties in proving mathematics need to be pursued by the application of learning approaches that can help the improvement of students' thinking stages, so that students' ability to prove can be developed optimally. One of the best approaches to develop students' abstract thinking abilities is through meaningful involvement in constructing and completing mathematical evidences [2].

Several learning approaches or strategies that develop mathematical proving ability for student level have been investigated by: Uhlig who developed an approach to understand and construct evidence in linear elementary algebra courses with the WWHWT approach (What, Why, How, What and Theorems) [11], Arnawa who uses learning strategies based on APOS theory (Action, Process, Object and Schema) in abstract algebra [10], Kusnandi who uses lessons with abductive-deductive strategy in the theory of number [9], and Yerison who uses learning strategies based on M-APOS theory (modified APOS) in real analysis courses [12]. 
The abductive-deductive approach has been researched before, which is also known as the learning approach that leads students to use a combination of abductive reasoning and deductive reasoning in solving mathematical proofs. A mathematical statements, traits, or theorems always consist of data or premise and conclusion, then to prove it using a deductive reasoning strategy from the premise and abductive reasoning from the conclusion, so that the two process are met and led to the process of proving the mathematical statements, traits, or theorems. This abductive-deductive approach is adopted from the APOS theoretical framework introduced by Dubinsky, which was based on APOS theory [13].

In addition to the application of an appropriate learning approach, to be able to measure the students' mathematical proving ability, it is also necessary to apply the assessment techniques in learning. Assessment is an integrated part of the learning program, which has a role in expressing the effectiveness of the learning process and the achievement of learning outcomes. Mathematical proving ability requires lecturers to being able to apply the right learning strategies or apply appropriate assessment techniques. Hence, authentic assessment can be used by lecturers, since authentic assessments are real performance-based assessments that require students associate the assignments to real situations directly, which include the assessment of process and learning outcomes to measure their competency in the form of knowledge, skills, and attitudes during learning process through the use of predetermined methods, measuring tools, and criteria. It was found that the implementation of authentic assessments in mathematics learning affected mathematics learning achievement and student motivation [14].

In this kind of case, the authentic assessment that can be used is a performance assessment. According to Slavin, through a performance assessment, students can be asked to apply everything that they have learned before. And for lessons with more limited time, students can be asked to do experiments, answer long texts, write in various styles, or solve math problems [15]. While according to Nitko, a performance task is a performance activity that requires students to demonstrate their achievements by producing or making something, creating a particular product or demonstrating a performance [16]. For that reason, the purpose of this study was to provide an overview of performance assessment instruments to measure students' mathematical proving abilities based on the abductive-deductive approach. 


\section{Methods}

This was a descriptive qualitative study, which provides an overview of performance assessment instruments and their rubrics in measuring students' mathematical proving abilities. The research method was literature study method.

\section{Results}

Mathematical proving problems are dealing with the problem on how to show the truth of a statement, traits, or theorem in mathematics, where the mathematical statement, trait, and theorem always consists of data or premise and conclusion. Solving the mathematical proving problem by using the abductive-deductive approach, is leading students to use a combination of reasoning abductively and deductively. Deductive reasoning is the process of thinking in processing the known facts to obtain new facts (the process of thinking is from general to specific). While abductive reasoning is a thinking process that starts from the conclusions and then creating assumptions regarding the conclusions that about to be reached.

In this study, an instrument was given used to measure students' mathematical proving abilities, which was mathematical proving questions presented along with the questions that would lead the student's thinking process by using abductive and deductive reasoning. The instrument given was an instrument of performance assessment, in order to see the mental work ability of students in solving these mathematical proving problems. Performance assessment was an assignment for student to apply their knowledge and skills to show that they can achieve learning targets [16]. The target of learning in this case is to be able to prove mathematical statements.

The following performance assessment instruments that was generated to measure mathematical proving abilities based on the abductive-deductive approach:

\section{Performance Assessment}

\begin{tabular}{ll}
\hline Course & $:$ Real Analysis I \\
Indicators & $: \begin{array}{l}\text { 1. To prove the traits related to the concept of set. } \\
2 \text {. To prove the traits related to the concept of function. }\end{array}$
\end{tabular}

1. Prove that if $A, B$ are sets and $B \neq \varnothing, A \subseteq B$ if and only if $A \cap B=A$.

\section{Answer the questions below to prove the statement above.}

a. Write the first implication of the bi-implication statement above.

b. What is the premise of the implications statement? 
c. What conclusions will be obtained from these implications?

d. What conditions can be obtained from the conclusions in c?

e. What consequences can be obtained from facts known in $b$ ?

f. Compile the facts or premises and consequences or implications as well as the conclusions and conditions of conclusions in the following scheme:

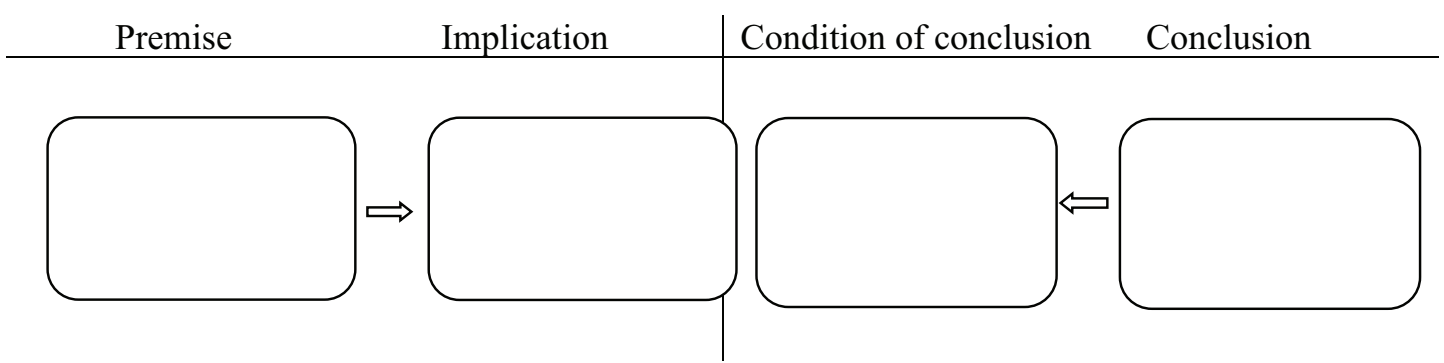

g. What relationship can be made from the conditions of conclusion with the implications of the premise in $f$ ?

h. Arrange a complete proof along with the reasons based on the structure of $b-g$ above.

i. Write the second implication of the bi-implication statement above.

j. What is the premise of the second implication statement?

k. What conclusions will be obtained from the statement of implications?

I. What conditions can be obtained from the conclusions in $\mathrm{k}$ ?

$\mathrm{m}$. What consequences can be obtained from the facts known in $\mathrm{j}$ ?

n. Compile the facts or premises and consequences or implications as well as the conclusions and the conditions of conclusions in the following scheme:

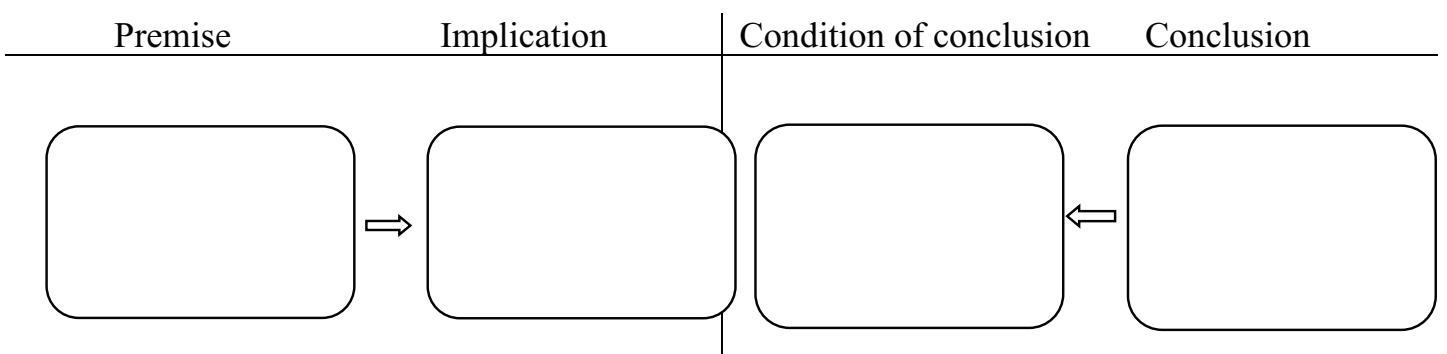

o. What relationship can be made from the conditions of conclusion with the implications of the premise in $n$ ?

p. Arrange a complete proof along with the reasons based on the structure of $j-0$ above.

q. What conclusions can be obtained from the first and second implications? 
2. Prove that if $f: A \rightarrow B$ is surjective $g: B \rightarrow C$ is surjective, then the composite $g \circ f:$ $A \rightarrow C$ is a surjective.

\section{Answer the questions below to prove the statement above.}

a. What is the premise of the statement above?

b. What conclusions will be obtained from the statement above?

c. What conditions can be obtained from the conclusions in b?

d. What consequences can be obtained from facts known in a?

e. Compile the facts or premises and consequences or implications as well as the conclusions and conditions of conclusions in the following scheme:

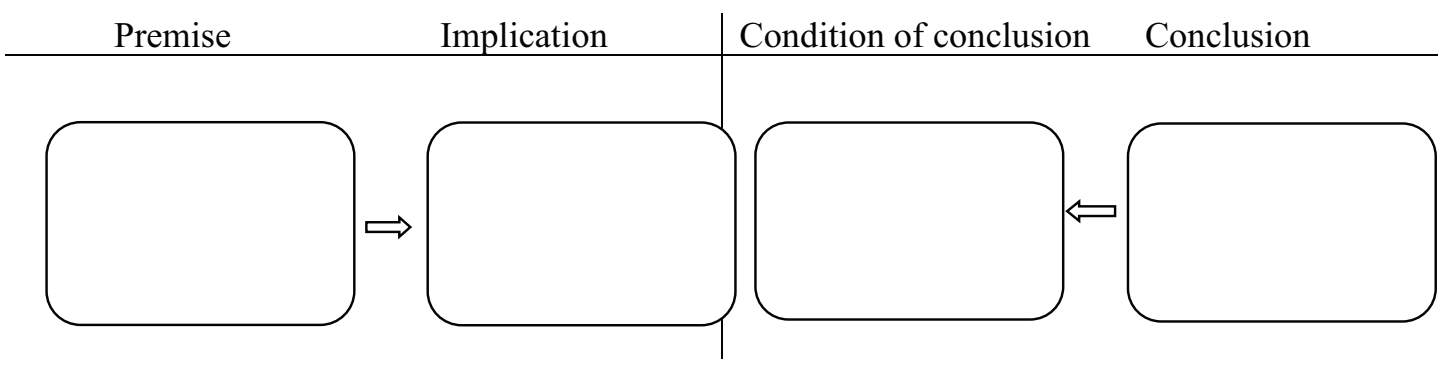

f. What conditions connect the conditions of conclusion to the implications of above premise?

g. Arrange a complete proof and the reasons based on the structure of $a-f$ above.

The competency standard that will be achieved from the assessment of mathematical performance instrument assignment is student's ability to prove mathematical statements or mathematical proving problems. Then the instruments were compiled into aspects or indicators of mathematical proving abilities which was synthesized from the opinions of Stylianides, Alcock \& Weber in KoSze Lee, Selden \& Selden, and Kusnandi, covering 6 aspects / indicators as follows: 1) identifying known facts (data or premise) and what must be shown (conclusions), 2) making connections or sequences between known facts and the elements of conclusions, 3) using proving methods, 4) completing the reasons for each step of proving process, 5) organizing and manipulating known facts to obtain a conclusion, and 6) constructing evidence logically and systematically [1,7-9].

Another characteristic of performance assessment is the availability of an assessment rubric. The assessment rubric used here is the analytic assessment rubric. The generated analytic rubrics of performance assessment based on aspects or indicators of mathematical proving ability: 
TABLE 1: Analytical Rubrics of Mathematical Proving Ability Performance

\begin{tabular}{|c|c|c|c|}
\hline No & Assessed Aspects & Criteria & Score \\
\hline \multirow[t]{4}{*}{1} & $\begin{array}{l}\text { Identifying data or premise and } \\
\text { conclusion }\end{array}$ & $\begin{array}{l}\text { Identify all data or premise and } \\
\text { conclusion }\end{array}$ & 3 \\
\hline & & $\begin{array}{l}\text { Identify almost all data or premise and } \\
\text { conclusion }\end{array}$ & 2 \\
\hline & & $\begin{array}{l}\text { Identify a few data or premise and } \\
\text { conclusion }\end{array}$ & 1 \\
\hline & & $\begin{array}{l}\text { Do not identify any data or premise and } \\
\text { conclusion }\end{array}$ & 0 \\
\hline \multirow[t]{4}{*}{2} & $\begin{array}{l}\text { Creating connections or sequences } \\
\text { between known facts and the elements } \\
\text { from conclusions }\end{array}$ & $\begin{array}{l}\text { Create connections or sequences } \\
\text { between known facts and the elements } \\
\text { from conclusions correctly }\end{array}$ & 3 \\
\hline & & $\begin{array}{l}\text { Create connections or sequences } \\
\text { between known facts and the elements } \\
\text { from conclusions almost correctly }\end{array}$ & 2 \\
\hline & & $\begin{array}{l}\text { Create connections or sequences } \\
\text { between known facts and the elements } \\
\text { from conclusions with a few mistakes }\end{array}$ & 1 \\
\hline & & $\begin{array}{l}\text { Do not create connections or sequences } \\
\text { between known facts and the elements } \\
\text { from conclusions correctly }\end{array}$ & 0 \\
\hline \multirow[t]{4}{*}{3} & $\begin{array}{l}\text { Using the mathematical proving } \\
\text { procedures }\end{array}$ & $\begin{array}{l}\text { Use the mathematical proving } \\
\text { procedures correctly }\end{array}$ & 3 \\
\hline & & $\begin{array}{l}\text { Use the mathematical proving } \\
\text { procedures almost }\end{array}$ & 2 \\
\hline & & $\begin{array}{l}\text { Use the mathematical proving } \\
\text { procedures with a few mistakes }\end{array}$ & 1 \\
\hline & & $\begin{array}{l}\text { Do not use the mathematical proving } \\
\text { procedures correctly }\end{array}$ & 0 \\
\hline \multirow[t]{4}{*}{4} & $\begin{array}{l}\text { Completing the reasons for each taken } \\
\text { step }\end{array}$ & $\begin{array}{l}\text { The evidence compilation correctly } \\
\text { completes the reasons for each taken } \\
\text { step }\end{array}$ & 3 \\
\hline & & $\begin{array}{l}\text { The evidence compilation almost } \\
\text { correctly completes the reasons for each } \\
\text { taken step }\end{array}$ & 2 \\
\hline & & $\begin{array}{l}\text { The evidence compilation completes a } \\
\text { few reasons for each taken step }\end{array}$ & 1 \\
\hline & & $\begin{array}{l}\text { The evidence compilation do not } \\
\text { correctly completes the reasons for each } \\
\text { taken step }\end{array}$ & 0 \\
\hline \multirow[t]{4}{*}{5} & $\begin{array}{l}\text { Organizing and manipulating the known } \\
\text { facts to get a conclusion }\end{array}$ & $\begin{array}{l}\text { Organize and manipulate the known } \\
\text { facts to get a conclusion correctly }\end{array}$ & 3 \\
\hline & & $\begin{array}{l}\text { Organize and manipulate the known } \\
\text { facts to get a conclusion almost correctly }\end{array}$ & 2 \\
\hline & & $\begin{array}{l}\text { Organize and manipulate the known } \\
\text { facts to get a conclusion correctly with a } \\
\text { few mistake }\end{array}$ & 1 \\
\hline & & $\begin{array}{l}\text { Do not organize and manipulate the } \\
\text { known facts to get a conclusion correctly }\end{array}$ & 0 \\
\hline
\end{tabular}




\begin{tabular}{|c|c|c|c|}
\hline No & Assessed Aspects & Criteria & Score \\
\hline \multirow[t]{4}{*}{6} & $\begin{array}{l}\text { Writing the proving process logically and } \\
\text { systematically }\end{array}$ & $\begin{array}{l}\text { The proving process are written logically } \\
\text { and systematically }\end{array}$ & 3 \\
\hline & & $\begin{array}{l}\text { The proving process are written almost } \\
\text { logically and systematically }\end{array}$ & 2 \\
\hline & & $\begin{array}{l}\text { The proving process are not really } \\
\text { written logically and systematically }\end{array}$ & 1 \\
\hline & & $\begin{array}{l}\text { The proving process are not written } \\
\text { logically and systematically }\end{array}$ & 0 \\
\hline
\end{tabular}

\section{Discussion}

Through the abductive-deductive approach, generally there are two types of actions that can be taken when dealing with a proving problem. First is to analyze every information provided in the data and premise, then arranging it to produce intermediate claims, and from these claims, the targets are synthesized to obtain next intermediate targets, and so on. These intermediate targets are another mental object that students might have had before. This process of obtaining intermediate targets from the data provided is called as a deductive process. While the second action is to analyze the expected final target, and formulate an intermediate target based on a certain rule (definition or theorem) so that it will suit the final target. This process of conditioning the intermediate targets toward the final targets is called an abductive process. Another stage of the process is to perform mental actions so that it can associate the result of deductive process' intermediate target and the result of abductive process' intermediate target, where the process will determine the success in proving mathematics, hence this process usually named as the key process.

Kusnandi provides a framework for the problem of proof of mathematics with an abductive-deductive approach illustrated as in the following figure [9]:

These following steps should be done to prove the statement of $A \Rightarrow B$ with the abductive-deductive strategy:
1)
$\stackrel{\mathrm{B}}{\mathrm{C}} \Rightarrow \mathrm{B}$
2)
$\mathrm{A}$
3) $\therefore \mathrm{C}$
$\mathrm{A} \Rightarrow \mathrm{C}$

C is a key concept that bridges data or premise A and conclusion B. Meanwhile, C $\Rightarrow B$ and $A \Rightarrow C$ are rules (definition, lemma or previous theorem).

The following example shows the process of theorem probing with abductivedeductive strategy:

\section{Theorem:}




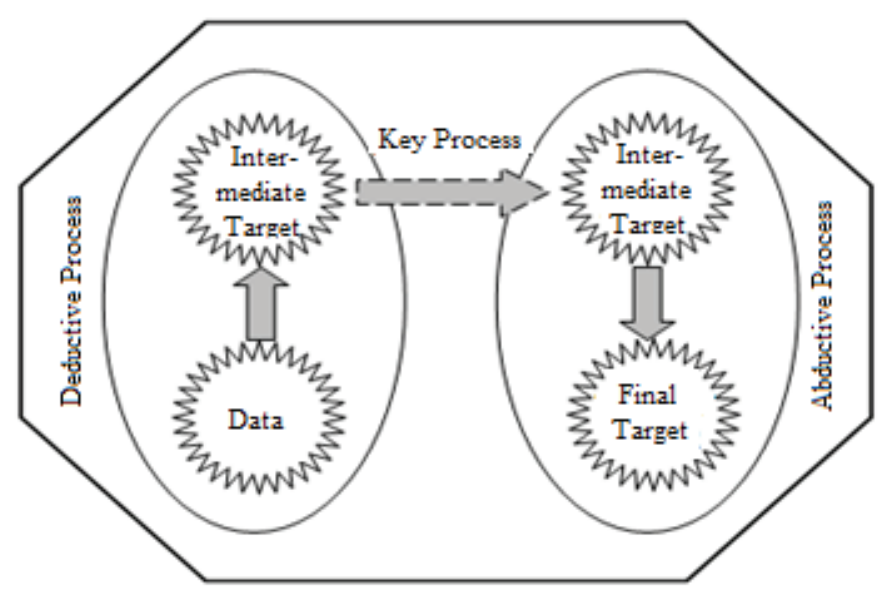

Figure 1: The Framework Model of Abductive-Deductive Strategy.

If $f: R \rightarrow R$ and $g: R \rightarrow R$ are injective function, then $f \circ g$ is also an injective function.

\section{The Proof:}

It is known that: $f$ and $g$ are injective function (premise)

It should be shown that: $f \circ g$ is injective function (conclusion).

Abductive Reasoning:

$f \circ g$ is injective function, with condition that it should be shown for each $x_{1}, x_{2}$ in $R$ with $(f \circ g)\left(x_{1}\right)=(f \circ g)\left(x_{2}\right)$ then $x_{1}=x_{2}$. To show that it work for every $x_{1}, x_{2}$ the operation is done by taking any $x_{1}, x_{2}$ in $R$ with the condition $(f \circ g)\left(x_{1}\right)=(f \circ g)\left(x_{2}\right) \Leftrightarrow f\left(g\left(x_{1}\right)\right)=f$ $\left(g\left(x_{2}\right)\right)$, then shown that $x_{1}=x_{2}$ (the intermediate target of abductive process).

Deductive Reasoning:

$f$ and $g$ are injective function, with condition for each $y_{1}, y_{2}$ in $R$ with $f\left(y_{1}\right)=f\left(y_{2}\right)$ then $y_{1}=y_{2}$ and for each $x_{1}, x_{2}$ in $R$ with $g\left(x_{1}\right)=g\left(x_{2}\right)$ then $x_{1}=x_{2}$. Hence for any $x_{1}, x_{2}$ and $y_{1}, y_{2}$ with the condition of $f\left(y_{1}\right)=f\left(y_{2}\right)$ and $g\left(x_{1}\right)=g\left(x_{2}\right)$ will obtain $y_{1}=y_{2}$ and $x_{1}=x_{2}$ (the intermediate target of deductive process).

Key Process:

$(f \circ g)\left(x_{1}\right)=(f \circ g)\left(x_{2}\right) \Leftrightarrow f\left(g\left(x_{1}\right)\right)=f\left(g\left(x_{2}\right)\right)$, because $f$ injective, so $f\left(g\left(x_{1}\right)\right)=f\left(g\left(x_{2}\right)\right.$ will obtain $g\left(x_{1}\right)=g\left(x_{2}\right)$. Because $g$ injective, so $g\left(x_{1}\right)=g\left(x_{2}\right)$ will obtain $x_{1}=x_{2}$. Because any $x_{1}, x_{2}$ with condition of $(f \circ g)\left(x_{1}\right)=(f \circ g)\left(x_{2}\right)$ will obtain $x_{1}=x_{2}$, hence for each $x_{1}$, $x_{2}$ with $(f \circ g)\left(x_{1}\right)=(f \circ g)\left(x_{2}\right)$ then $x_{1}=x_{2}$.

Therefore, by a condition, a conclusion can be obtained $f \circ g$ is an injective function.

To understand the example of mathematical proving process above, the scheme of abductive-deductive process is shown in Figure 2. 


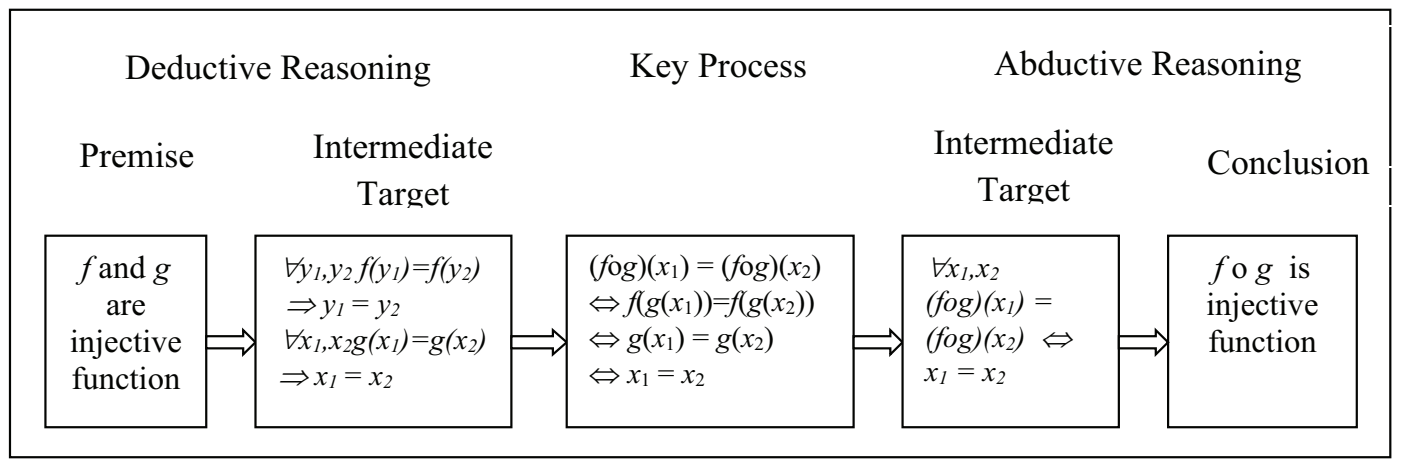

Figure 2: An Example of Mathematical Proving Process.

There is a pattern that illustrates the abductive and deductive reasoning for each mathematical proving question above, which is the question "What conditions can be obtained from the conclusion?" Then to answer that, students can use abductive reasoning, which in mathematics known as working backward. Abductive reasoning is a valid reasoning known as reverse engineering which is similar to regressive reasoning or working backward [17]. Meanwhile, the question "What effect can be obtained from known facts?" can be answered using deductive reasoning. Deductive reasoning is the hallmark of reasoning in mathematics. In accordance with the opinion of Ruseffendi, mathematics is knowledge of organized structure, its properties and theories are made deductively based on elements that are not defined, axioms, traits or theories that have been proven true [18]. For the question "What conditions connect the conditions of conclusions to the implications of the premise?" when answering those, students get a key process from the process of proving mathematical statement.

According to Mueller, in developing authentic assessments some signs are required, namely: identification of standards (learning objectives), selection of authentic tasks, identification of evaluating assignments criteria, and creation of assessment rubrics [19]. Thus the performance assessment characteristics are the existence of competency standards to be achieved, and then the availability of job descriptions that require student's performance to achieve standardized competencies and the availability of rubric or assessment criteria to measure the performances. According to Arends, anaIytical rubric requires the scorer to separately assess individual components or tasks related to performance [20], and according to Setiadi, the performance assessment using analytic methods, is to provide an assessment (score) based on various different aspects related to the performance being assessed [21]. Thus, using analytic rubrics to assess performance can describe the task completely and in detail, which includes aspects of the task as well as its criteria and score levels. 


\section{Conclusion}

To measure mathematical proving abilities, performance assessment instruments can be used. Those instruments contain abductive and deductive approach aspects and also integrate the process of abductive and deductive reasoning in the steps of solving mathematical proving problems. The instrument for evaluating mathematical proving abilities can be applied to other subjects that are loaded with mathematical proving problems, such as Abstract Algebra and Theory of Number.

\section{References}

[1] Selden, A. and Selden, J. (2003). Validations of Proof Considered as Texts: Can undergraduates Tell Whether an Argument Proves a Theorem? Journal for Research in Mathematics Education, vol. 34, issue 1, pp. 4-36.

[2] Epp, S. (2003). The Role of Logic in Teaching Proof. The American Mathematical Monthly, vol. 110, issue 10, pp. 886-899.

[3] Lee, J. K. (2002). Philosophical Perspective on Proof in Mathematics Education. Philosophy of Mathematics Education Journal, vol. 16. Retrieved from http://www. ex.ac.uk/ PErnest/pome16/does/lee.pdf.

[4] Douek, N. (1999). Some Remarks about Argumentation and Mathematical Proof and Their Educational Implications. In I. Schwank (Ed.), Mathematics Education I: Volume I. Osnabrück: Forschungsinstitut für Mathematikdidaktik and ERME.

[5] Dickerson, D. S. (2008). High School Mathematics Teachers Understandings of the Purposes of Mathematical Proof (Dissertation). New York: Syracuse University.

[6] Maya, R. (2011). Mathematical Understanding and Proving Abilities: Eksperiment With Undergraduate Student by Using Modified Moore Learning Approach. IndoMS. J.M.E., vol. 2, issue 2, pp. 231-250.

[7] Lee, K. (2011). Students Logical Reasoning and Mathematical Proving of Implications (Dissertation). Michigan: Michigan State University.

[8] Stylianides, A., Stylianides G. and Philippou G. (2004). Undergraduate Students Understanding of The Contraposition Equivalence Rule in Symbolic and Verbal Contexts. Educational Studies in Mathematics, vol. 55, pp. 133-162.

[9] Kusnandi. (2008). Pembelajaran Matematika Dengan Strategi Abduktif-Deduktif Untuk Menumbuh kembangkan Kemampuan Membuktikan Pada Mahasiswa (Disertasi). Bandung: Universitas Pendidikan Indonesia. 
[10] Arnawa, I. M. (2006). Meningkatkan Kemampuan Pembuktian Mahasiswa dalam Aljabar Abstrak Melalui Pembelajaran Berdasarkan Teori APOS (Disertasi). Bandung: Universitas Pendidikan Indonesia.

[11] Uhlig, F. (2002). The Role of Proof in Comprehending and Teaching Elementary Linear Algebra. Educational Studies in Mathematics, vol. 50, issue 3, pp. 335-346.

[12] Yerison. (2011). Peningkatan Kemampuan Pembuktian dan Kemandirian Belajar Matematik Mahasiswa Melalui Pendekatan M-Apos (Disertasi). Bandung: Universitas Pendidikan Indonesia.

[13] Tall, D. (1998). The Cognitive Development of Proof: Is Mathematics Proof for All or Some? Presented at Conference of the University of Chicago School Mathematics Project, Chicago, United States of America.

[14] Balik, I. W. (2012). Pengaruh Implementasi Asesmen Autentik Terhadap Prestasi Belajar Matematika dan Motivasi Berprestasi (Eksperimen pada Peserta Didik Kelas VIII SMP Negeri 3 Gianyar). Jurnal Penelitian dan Evaluasi Pendidikan, vol. 2, issue 2, pp. 1-14.

[15] Slavin, R. E. (2011). Psikologi Pendidikan Teori dan Praktek, Terjemahan Marianto Samosir. Jakarta: Indeks.

[16] Nitko, A. J. (2008). Educational Assessment of Students (3 ${ }^{\text {rd }}$ ed.). New Jersey: Prentice-Hall.

[17] Chong, H. Y., DiGangi, S. and Jannasch, A. (2008). The Role of Abductive Reasoning in Cognitive Based Assessment. Elementary Education Online, vol. 7, issue 2, pp. 310-322.

[18] Ruseffendi, E. T. (2006). Pengantar Kepada Membantu Guru Mengembangkan Kompetensinya dalam Pengajaran Matematika untuk Meningkatkan CBSA. Bandung: Tarsito.

[19] Johnson, R. S. J., Mims-Cox, S. and Doyle-Nichols, A. (2010). Developing Portofolios in Education: A Guide to Reflection, Inquiry, and Assessment. Los Angeles: SAGE Publication.

[20] Arends, R. I. (2013). Belajar untuk Mengajar, terjemahan Made Frida Yulia. Jakarta: Salemba Humanika.

[21] Setiadi, H. (2006). Penilaian Kinerja. Jakarta: Puspendik Balitbang Depdiknas. 